99

\title{
COLONIAL ARMY RECRUITMENT PATTERNS AND POST-COLONIAL MILITARY COUPS D'ÉTAT IN AFRICA: THE CASE OF NIGERIA, 1966-1993
}

\author{
Dr E. C. Ejiogu, Department of Sociology \\ University of Maryland
}

\begin{abstract}
Since time immemorial, societies, states and state builders have been challenged and transformed by the need and quest for military manpower. ${ }^{1}$ European states relied on conscript armies to 'pacify' and retain colonies in parts of the non-European world. These facts underscore the meticulous attention paid by the British to the recruitment of their colonial forces in Africa. In the Niger basin for one, conscious efforts were made by individual agents of the British Crown and at official level to ensure that only members of designated groups were recruited into those colonial forces that facilitated the establishment of the Nigerian supranational state. The end of colonial rule and shifts in military recruitment policies hardly erased the vestiges of colonial recruitment from the Nigerian military. The study on which this article is based and which examines Britain's policies on military human resource recruitment as state-building initiatives, argued that military coups d'état in Nigeria can be traced back to colonial and post-colonial recruitment patterns for military human resources.
\end{abstract}

\section{Introduction}

Nigeria, built in the late nineteenth century by British colonial intervention, is Africa's most populous country. ${ }^{2}$ Events in Nigeria ${ }^{3}$ since October 1, 1960, when it acquired political independence from Britain, furthermore attest to the political instability that the country experiences. Table 1 shows that in the period 1960-1999, Nigeria experienced eleven different central governments. Eight of those governments were military regimes. Two were headed by elected civilians, and one was headed by an appointed civilian. 
Frynas ${ }^{4}$ described Nigeria's elected civilian governments as unstable. According to Frynas, this instability is characterised by coups d'état led by soldiers. Based on Frynas' logic, one would be justified to argue that Nigeria's military-led regimes were as unstable as the civilian-led governments they over-threw. Table 1 shows that two military regimes, i.e. that by Murtala Muhammed (1975-6) and another by Ibrahim Babangida (1985-93) were themselves wracked by coup attempts. ${ }^{5}$ The other three military regimes, i.e. by General Aguiyi Iron (1966-67), by General Yakubu Gowon in 1967-75, and by Muhammadu Buhari (1983-85) were deposed in successful army-led coups. Babangida's regime replaced itself with an appointed military-involved successor in the guise of an Interim National Government (ING) (1993-94), headed by Ernest Shonekan, a civilian. In 1994, General Sanni Abacha ousted the ING of which he was the Defence Secretary and was succeeded by yet another military regime led by General Abdul Salami Abubakar after the sudden death of Abacha in 1998.

Competing accounts and explanations of coups d'état in Nigeria and the rest of Africa abound in area studies, history, sociology, and political science literatures. ${ }^{6}$ Each account of African coups has furnished valid explanations. Most if not all authors of those accounts acknowledge that coups are obvious indicators of political instability evident on the continent. It is therefore on the strength of such acknowledgements that the authors of those accounts analysed coups either in the specific contexts of individual African states or as patterns based on methodological perspectives that furnish "more general hypotheses and theories regarding military involvement in third-world politics". ${ }^{7}$ Although reasons such as factionalism in the military and centrality of the military in society, given in some accounts as the causes of military coups d'état in African states, do hold some validity, their authors have not by any means accomplished definitive accounts of the root causes of coups in Africa. ${ }^{8}$ For instance, factionalism could be an outcome of conscious recruitment patterns that are unaccounted for in rigid statistical computations on which explanations of coups in African states and their causes have been based.

Unlike previous studies, the case study on which this article is based, examined various policies and mindsets that have guided and influenced the recruitment of indigenous men into colonial military forces in the areas of the Niger basin, which later became Nigeria, as aspects of state-building initiatives in the period that began during 1890 and ended in 1960 when British rule ended in Nigeria. ${ }^{9} \quad$ It is further argued that British state-building measures encouraged the evolution of state structures that produced a legacy and catalyst for some of the military coups that afflicted post-independence politics in Nigeria. The current case 
study consequently responded to the following research question: To what extent and degree did the policy that guided the recruitment of indigenous men into military forces in colonial and early post-colonial Nigeria establish a legacy of coups in the armed forces in the post-independence era? ${ }^{10}$ The units of analysis are the coup events. ${ }^{11}$ In each case, inferences were drawn from the nationality and religious affiliation of coup plotters and participants, their motives, and the nationality of their victims to buttress the arguments made in this article.

Due to the limited scope covered, the risk of limited methodological rigor, which could affect the generalisability of findings and conclusions, single-case case studies are often viewed with scepticism in social science research. ${ }^{12}$ However, in spite of the scepticism about their possible shortcomings, single-case study designs are still popular amongst practitioners ${ }^{13}$ who employ such designs in mostly descriptive and exploratory studies in which 'no comparison with another group is made' and 'no hypothesis is tested'. ${ }^{14}$ One of the outstanding relevancies of the one-case methodology, which applies to the present study, is that which derives from the rationale that irrespective of the colonial power in Africa, colonial policies were state-building initiatives that were largely driven by what can, for lack of a more succinct term, be called the 'imperial cause'. In other words, the over-arching similarity in the motives of each of the European powers that acquired colonial possession(s) in Africa in the late nineteenth century was the quest to achieve a 'colonial project'. ${ }^{15}$ Any evident differences in how these European powers went about to achieve that quest hardly matters in the sense that the outcome in each case is similar. In the context of this study, the expressed limitations of single-case case studies would not necessarily apply, as those conclusions reached on Nigeria that share similarities with other African cases, could still be applied to the latter. Hence, Martyn Denscombe's admonition that “... research should produce findings from which generalizations can be made" when "the people, events or data" are employed possess characteristics that can "help to identify and explain significant factors related to other instances more generally (theory relevance)"16 is apt and quite relevant here.

Table 1: Governments in the ‘Nigerian’ supra-national state, 1960-1999.

\begin{tabular}{|l|l|l|l|l|}
\hline Duration & $\begin{array}{c}\text { Head of } \\
\text { state }\end{array}$ & Government & \multicolumn{1}{|c|}{$\begin{array}{c}\text { Ethnic } \\
\text { origin }\end{array}$} & How rule ended \\
\hline $1960-66$ & Balewa & Civilian & Hausa/North & Coup/assassination \\
\hline 1966 & Ironsi & Military & Igbo/South & Coup/assassination \\
\hline $1966-75$ & Gowon & Military & Angi/North & Coup \\
\hline
\end{tabular}


102

\begin{tabular}{|l|l|l|l|l|}
\hline $1975-76$ & Mohammed & Military & Hausa/North & $\begin{array}{l}\text { Coup } \\
\text { attempt/assassination }\end{array}$ \\
\hline $1976-79$ & Obasanjo & Military & Yoruba/South & Elections \\
\hline $1979-83$ & Shagari & Civilian & Fulani/North & Coup \\
\hline $1984-85$ & Buhari & Military & Fulani/North & Coup \\
\hline $1985-93$ & Babangida & Military & North & Stepped down \\
\hline $1993-94$ & Shonekan & Appointed & Yoruba/South & Coup \\
\hline $1994-98$ & Abacha & Military & Kanuri/North & Sudden death \\
\hline $1998-99$ & Abubakar & Military & Hausa/North & Sham election \\
\hline
\end{tabular}

Source: Jedrzej G. Frynas, "Political Instability and Business: Focus on Shell in Nigeria,” Third World Quarterly 19, 3(1998): 457-78.

\section{Case presentation}

Nigeria's armed forces originated from military forces assembled by different British agents whose activities culminated in the colonisation of parts of the Niger basin, which became Nigeria. ${ }^{17}$ This tendency is not peculiar to Nigeria, which is why Claude E. Welch, Jr. observed that "the armed forces of contemporary Africa originated from the forces of European occupation and control". ${ }^{18}$ Welch underscored the validity of his own observation by citing the argument by W. F. Gutteridge that "[t]he armies of Africa today are, therefore, direct descendants of the colonial forces raised in their territories by imperial powers". ${ }^{19}$ In Africa, the role of the army is paramount in Britain's colonial endeavours, ${ }^{20}$ following the decision to amalgamate the two 'protectorates' of northern and southern Nigeria into a united Nigerian state, which marked the commencement of de facto colonialism in the lower Niger basin. As late as the eve of political independence on October 1, 1960, i.e. 1958, all decisions that related to the Nigerian army, which was then called the Queen's Own Nigeria Regiment, were on the exclusive list of the British War Office. ${ }^{21}$ The stakes were just too high for imperial authorities in London to entrust army-related matters in Nigeria and the rest of West Africa into the hands of anyone else. $^{22}$

All British agents who operated in the Niger basin relied on disaffected individuals to raise military forces for their conquest of its inhabitants. For instance, during his tenure (1861-73) as the lieutenant governor of the Lagos Crown Colony, ${ }^{23}$ Lt. John Glover enforced compliance to Crown authority with the militia that he raised earlier on as an imperial adventurer/agent in Yorubaland from runaway Hausa slaves. ${ }^{24}$ In 1903, almost half a century later, the bulk of the forces 
that Frederick Lugard ${ }^{25}$ deployed in his campaign against the Fulani rulers of Hausaland comprised of runaway Hausa slaves and other disaffected and marginalised individuals in Hausaland. ${ }^{26}$ By doing so, he gave them the opportunity to participate in his campaign against their Fulani overlords. Ironically, due to the alliance that subsequently evolved between British rule and the Fulani rulers, Lugard's defeat of the Fulani could not result in the abolition of their autocratic political system, which denied the majority in Hausaland full participation in the affairs of their society. Lugard let the Hausa-Fulani ruling classes remain in power as indirect rulers after they had sworn to remain loyal to the Crown. ${ }^{27}$ Thus, as early as the beginning of the twentieth century, Lugard instituted loyalty to Britain's imperial cause as one of the major qualifying criteria for the recruitment of indigenous men into colonial forces. Henceforth, the inhabitants of the upper Niger, which as far as the British were concerned was synonymous with the Caliphate society, were considered the embodiment of that loyalty.

With the consolidation of all the irregular forces into a regular army and their assignment to the role of the defender of the incipient Nigerian colonial state, loyalty to the imperial cause was further entrenched as the underlying policy that guided the recruitment of indigenous personnel into the rank and file. Furthermore, some nationalities were attributed with 'martial traits' and called 'martial tribes'. Members of such tribes were deemed suitable for recruitment. The definition of 'martial traits' was at best unclear. More often than not 'martial tribes' were inhabitants of hinterland areas, but the determination of their qualification as a quality military human resource was based solely on the remoteness of their homeland, which rendered them detached from the inhabitants of areas where colonial urban centres evolved and flourished in the coastal south. However, the truth is that the so-called martial traits derived primarily from the mindset of the coloniser who believed that soldiers recruited from remote parts of colonised territories would, because of the remoteness of their homeland, be more psychologically detached from other nationalities that inhabit the areas where the urban centres flourished. The underlying logic of that belief was that soldiers from remote areas would be more effective in the suppression of anti-colonial uprisings in the urbanised areas where their detachment and lack of affinity with the locals would not constitute a hindrance to their mission when deployed. ${ }^{28}$ That mindset seemed to have prevailed in and even resonated amongst all European colonial administrators in Africa.

Lugard associated Western-educated residents of Nigeria's urban centres with anti-colonial sentiments. In fact, his attitude towards them was hostile, and his 


\section{4}

relationship with them was at best fractious. ${ }^{29}$ His aversion for Western-educated urbanites, most if not all of whom were in the lower Niger, was such that urban residence and Western education became attributes that rendered people unfit for recruitment. The same assertion could be made about the exposure of indigenous people to Christianity. ${ }^{30}$ Hence, nationalities of the lower Niger basin amongst whom Western education and Christianity took roots earlier were deemed unsuitable human resource material for colonial military service primarily because they were unfavourably disposed to colonial authority, which Lugard attributed to their exposure to Western education and Christianity. ${ }^{31}$

When manpower pressures compelled the British War Office during World War I to send a recruitment mission to West Africa in 1916, this mission was tasked to pay particular attention to the "pagan areas" and not to the Christianised nationalities of the south as viable sources of recruits. The praise of "pagan areas" by A. Haywood and F. A. Clark in their history of the West African Frontier Force as suitable sources of "useful and steady expanding volume of material" for colonial armed forces in the territories is testimony that the mission heeded the aforementioned recommendation. ${ }^{32}$ Translation of the mindset that inhabitants of the "pagan areas" made the best soldiers into practice explains why the Tiv or Munshi, the Numan, the Tangele, the Dakakori, and other remote inhabitants were exclusively recruited as infantrymen into what became the Nigerian army. ${ }^{33}$

The determination of who was suitable or unsuitable for service in colonial forces in Africa was therefore both a subjective and stereotypical decision made by colonial administrators who rose to the occasion in the course of their service to the Empire. In the upper Niger region, Lugard recruited disaffected individuals and used them to defeat the Fulani rulers, whom he quickly embraced as his allies.

As expected, Lugard and his successors were favourably disposed to conservative Islam, which provided ideological support for Fulani rulers and, by extension, for Crown authority. Thus, history repeated itself the third time as conservative Islam produced $^{34}$ "the cult of the Muslim [and] led to support for men and institutions that were despotic and corrupt". ${ }^{35}$ Furthermore, in the upper Niger region, colonial education was consciously used to propagate conservative Islam beyond Hausaland, in the quest to create an 'imagined community' of Northerners, aimed partly at enlarging the pool of future recruits. ${ }^{36}$ Ironically, even Yoruba Muslims were deemed unfit for recruitment. ${ }^{37}$ 
My assessment, therefore, is that in the Niger basin, the more democratic a nationality's indigenous authority patterns and influence relations were, and the more attached its members were to these, the more unfit they were deemed for recruitment. (No wonder therefore that an alliance swiftly evolved between HausaFulani rulers and Lugard, their conqueror). The centralised and autocratic features of Caliphate rule were indeed responsible for disposing Caliphate authority patterns to find consonance and congruence in and with the authority patterns of the imposed colonial state. $^{38}$ The incidence of democratic authority patterns and influence relations or, their absence in the nationalities that inhabit the Niger basin, were crucial elements in the litmus test for loyalty to imperial authority. One can infer that it was partly the absence of similar features in the Igbo and Yoruba authority patterns that rendered them and other southern nationalities unfit allies of colonial authority and made their people to be seen as incapable of loyalty to the Crown. That suspicion was largely fulfilled because colonial policies that succeeded in the upper Niger region quickly provoked anti-colonial riots when they were extended to the lower Niger region. ${ }^{39}$ One such policy was direct taxation, which was introduced with success in the upper Niger region, which but provoked extensive riots amongst the Yoruba, ${ }^{40}$ the Igbo, and others in southeast areas of the lower Niger in 1929-30. ${ }^{41}$

During colonialism, the Nigerian army remained the machine for internal repression of first and last resort in the hands of colonial administrators, who deployed it handily to counter and neutralise internal threats to colonialism. In 1929-30, for instance, the army was deployed to suppress the anti-tax uprising by women in parts of Igboland and the neighbouring Ibibiland. ${ }^{42}$

Convinced that the upper Niger regions had been transformed successfully into a homogenous polity, which they could rule indirectly through their allies, the Hausa-Fulani ruling classes, colonial administrators felt secure enough to institutionalise exclusive recruitment of Hausa speakers and adopted the Hausa language as the official language in the army. But their efforts to transform the upper Niger region produced mixed socio-political outcomes. Like similar efforts in social engineering elsewhere in history in later years, aspects of its outcomes saddled society in Nigeria with undesirable consequences. Gutteridge underscored the validity of this assertion when he observed that preference for a culture and the recruitment of speakers of a language that discouraged literacy in Western technology and education, produced the legacy of an educational and technological vacuum in the army, and helped to spawn serious political consequences in the polity after colonialism. ${ }^{43}$ One such outcome is the legacy of social cleavage in the 
army, which deepened with the outbreak of World War II when the need for skilled personnel gave rise to the recruitment of Igbo and other nationalities with the requisite skills in Western education as tradesmen, drivers, mechanics, clerks, and so on into the rank and file. It is noteworthy to reiterate at this point that events later proved that Britain's social engineering activities aimed at transforming the upper Niger region into a homogenous polity were largely unsuccessful.

\section{Immediate and extended outcomes}

Within a few years after World War II had ended, the army was transformed from an exclusive force of northern "pagan tribes" commanded by British officers and NCOs into one that was composed of artillery units and infantry battalions. Table 2 below indicates that by 1949 there were just three indigenous men in the officer corps - all from nationalities in the lower Niger region. However, about 70-80 percent of the rank and file was composed of illiterate Hausa speakers from inhabitants of the upper Niger region. In the rank and file also, albeit nominally, there were skilled tradesmen who possessed some Western education, who were mostly either Igbo or from other lower Niger entities.

The paradox is that, while the divisions that resulted from the fractured composition of the army continued to serve Britain's imperial cause well, even up until the last days of colonialism, it helped to open up Nigeria for political instability immediately after independence. The following anecdotal case aptly substantiates the assertion about the benefits of the fractured composition of the army to the imperial cause.

In 1952, a mutiny by some 100 clerks who were attached to the Command Ordnance Depot in the Yoruba suburb of Yaba, near Lagos, over poor living conditions, was quickly suppressed by a detachment of Military Police and infantry riflemen, before it claimed the lives of the British officers who were in charge of the Depot. The mutineers were all members of southern nationalities ${ }^{44}$ while the riflemen and military police who were deployed to suppress the revolt were all northerners. ${ }^{45}$ It took only six years after the end of colonial rule in 1960 before the social divisions and rifts exploded into coups and coup attempts. 
Table 2: List of indigenous men commissioned in the officer corps in the period 1946-57.

\begin{tabular}{|c|c|c|}
\hline Officer & Origin (Geographical and Ethnic) & $\begin{array}{c}\text { Year of } \\
\text { Commission }\end{array}$ \\
\hline Bassey & South (Efik) & 1946 \\
\hline Ironsi & " (Igbo) & 1949 \\
\hline Ademulegun & " $\quad$ (Yoruba) & 1949 \\
\hline Shodeinde & " (Yoruba) & 1950 \\
\hline Maimalari & North (Kanuri) & 1953 \\
\hline Lawan & " $\quad$ (Kanuri) & 1953 \\
\hline Ogundipe & South (Yoruba) & 1953 \\
\hline Adebayo & " (Yoruba) & 1953 \\
\hline K. Muhammed & (Kanuri) & 1954 \\
\hline Largema & " $\quad$ (Kanuri) & 1954 \\
\hline Nwawo & South (Igbo) & 1954 \\
\hline Fajuyi & South (Yoruba) & 1954 \\
\hline Imo & South (Igbo) & 1955 \\
\hline Pam & North (Birom) & 1955 \\
\hline Kurobo & South (Ijaw) & 1955 \\
\hline Effiong & South (Efik) & 1956 \\
\hline Njoku & South (Igbo) & 1956 \\
\hline Onuaguluchi & South (Igbo) & 1956 \\
\hline Ojukwu & South (Igbo) & 1957 \\
\hline Ejoor & South (Igbo) & 1956 \\
\hline Banjo & " (Yoruba) & 1956 \\
\hline Unegbe & " (Igbo) & 1956 \\
\hline Gowon & North (Angi) & 1956 \\
\hline Okwechima & South (Igbo) & 1956 \\
\hline Madiebo & " $\quad$ (Igbo) & 1956 \\
\hline Ekanem & " (Efik) & 1957 \\
\hline Nzefili & " (Igbo) & 1957 \\
\hline Ogbonnia & " $\quad$ (Igbo) & 1957 \\
\hline
\end{tabular}

Sources: Robin Luckham, The Nigerian Military: A Sociological Analysis of Authority and Revolt, 1960-67, Cambridge: At the University Press, 1971:343-4) and N. J. Miners, The Nigerian Army, 1956-1966 (London: Methuen, 1971:38-9). 
The social cleavage evolved even further under Hausa-Fulani political leaders to whom the British consciously entrusted political power just before the end of colonial rule. The imminent end of colonial rule forced yet another shift on the recruitment policy of what was about to become the Nigerian army. As is evident in Table 2, from the 1950s onward, the departure of more and more British officers opened the officer corps to indigenous men who possessed the requisite Western education who were recruited to replace departing British officers under the policy of 'Nigerianization'. ${ }^{46}$ Table 3 clearly portrays the impact of the aforementioned policy on the officer corps. The table reveals that in January 1960, only 50 (or 18\%) of the officer corps were Nigerians, while the rest (228) were British. By 1966, there were no more British officers in the army and the size of the corps had increased to 517, i.e. 336 combat and 181 non-combat officers.

Table 3: The impact 'Nigerianization' on the officer corps in the Nigerian army, 1960-66.

\begin{tabular}{|c|c|c|c|c|}
\hline \multicolumn{5}{|c|}{ Number of Nigerian Officers } \\
\hline Date & $\begin{array}{c}\text { Number of } \\
\text { British Officers }\end{array}$ & Combat & $\begin{array}{c}\text { Non- } \\
\text { Combat }\end{array}$ & \% Nigerian Officers \\
\hline 1 Jan. '60 & 228 & 48 & 2 & 18 \\
\hline 1 Jan. '62 & 156 & 107 & 50 & 50 \\
\hline 1 Jan. '64 & 47 & 240 & 132 & 89 \\
\hline 1 Jan. '66 & 0 & 336 & 181 & 100 \\
\hline
\end{tabular}

Source: Robin Luckham (1971:163).

The recruitment of indigenous men who possessed Western education played to the advantage of lower Niger ethnic groups. ${ }^{47}$ However, on the eve of independence, each nationality's response to the opportunity to enlist in the army was a function of the following: the texture of the asymmetrical relationship between leaders and subordinate members of the larger society, the degree of the latter's participation in the affairs of their respective societies, and leadership responsiveness. The character and outcome of each nationality's response to enlist saddled Nigeria with implications that would only become evident later. In the north, especially in Hausaland, where society was devoid of facilitated channels of participation for ordinary members of society, it took an elaborate and extensive campaign by prominent Hausa-Fulani individuals, including Ahamadu Bello, the Sardauna of Sokoto, who was also the Regional Premier, to convince boys from secondary school to enlist in the officer corps. The Sardauna harped on "the former 
martial glories of the jihads" 48 and called on the students to "show that they were not women". ${ }^{49}$

When northern politicians assumed state power in 1960, they enacted policies that increased the number of northerners in the corps. For instance, they lowered entry qualifications and drastically slashed failure rates in selection tests into the Nigerian Military Training College with the aim of attracting more northern enlistees. ${ }^{50}$ One outcome of such preferential policies over the years in the army is that northern beneficiaries of those patron-client incentives regarded themselves as cohorts. Events showed that their allegiance was primarily skewed towards their civilian patrons and senior northern colleagues.

In the lower Niger region, where participation of all and sundry in the affairs of society is a hallmark of public life in each ethnic grouping, enlistment into the officer corps was entirely left to the career choices of individual school leavers. In Igboland, where society does not thrive on patron-client cleavage, young school leavers who enlisted were not prompted by their political leaders. As commissioned officers, events later showed that, unlike their northern counterparts, most of them regarded themselves as free-thinking citizens. Personal narratives and other published accounts attest to the fact that their decision to enlist derived from the zeal and conviction that they could use the army to build and transform Nigeria into a truly democratic state. ${ }^{51}$

Table 4 outlines the immediate impact of the policies implemented by northern politicians to improve the enlistment of northerners into the corps after their assumption of political power in 1960. It shows that before independence in 1960 , about $68 \%$ of the officer corps was Igbo, while $14 \%$ was from the north. ${ }^{52}$ The percentage of officers from each of the three regions, as shown in Table 4, before and after the introduction of the quota system that pegged officer cadet enlistment at $50 \%, 25 \%$, and $25 \%$ in favour of the North, East and West respectively, is indicative of the assertion that northern politicians took advantage of their assumption of power to stack the corps in favour of the North. 
Table 4: How the quota policies affected the enlistment of men from different parts of the country into the officer corps.

\begin{tabular}{|l|c|c|c|c|}
\hline & North & $\begin{array}{c}\text { West } \\
\text { (South) }\end{array}$ & $\begin{array}{c}\text { East } \\
\text { (South) }\end{array}$ & $\begin{array}{c}\text { South } \\
\text { Cameroons }\end{array}$ \\
\hline Pre-Independence & $8(14 \%)$ & $10(17 \%)$ & $37(65 \%)$ & $2(3.5 \%)$ \\
\hline (Earlier-1959) & & & & \\
\hline Pre-Quota & $21(32 \%)$ & $12(18 \%)$ & $29(45 \%)$ & $3(5 \%)$ \\
\hline$(1946-59)$ & & & & \\
\hline Post-Quota & $104(48 \%)$ & $46(21 \%)$ & $66(31 \%)$ & ---- \\
\hline$(1960-66)$ & & & & \\
\hline Total & $133(39 \%)$ & $68(20 \%)$ & $132(39 \%)$ & $5(2 \%)$ \\
\hline
\end{tabular}

Source: N. J. Miners (1971:119).

The Yoruba, who like the Igbo and the other southern groups, had embraced Western education without let or hindrance from the time it was introduced and peddled by Christian missionaries, constituted about $17 \%$ of the corps, as shown in Table 4, an insignificant proportion compared to the Igbo. The explanation for the disparity is that at first, unlike the Igbo, the Yoruba showed very low enthusiasm for the army. In 1966, there were a mere 700 Yoruba soldiers in the 10500 strong Nigerian army. ${ }^{53}$

Spirited efforts by Hausa-Fulani politicians to influence the enlistment of upper Niger school leavers in the 1960s could imply that, irrespective of the predominance of northerners in the rank and file, the politicians were troubled by the sparse presence of northerners in the corps. It is no overstatement to argue that when colonialism ended in 1960 the Nigerian army hardly reflected the composition of the envisaged Nigerian supra-national state.

The end of colonialism did not end skewed recruitments in favour of the North. Signs that the British were more intent on entrusting political power and control to their Hausa-Fulani allies - who they felt would run the affairs of the 


\section{1}

country in ways that would continue to guarantee their interests - became apparent as independence neared. One such sign was the conduct of the 1951-2 general census, and another the running of the 1959 general elections. It turned out that the outcome of the latter was predicated on the outcome of the former. Both exercises, which set the stage eventually for Britain's disengagement from direct political administration of Nigeria in 1960, are believed to have been manipulated to produce outcomes favourable to the Hausa-Fulani ruling classes and their party, the Northern People's Congress (NPC). ${ }^{54}$ Robin Luckham argues that the transfer of power to the Hausa-Fulani on the platform of the NPC was a calculated measure devised and implemented by "colonial officials working in the North". ${ }^{5}$ Luckham insists that there was "no doubt [that] the British government felt that a Nigerian government controlled by conservative Northern politicians would be more 'stable' and favourable to its interests". 56

Table 5: Distribution of regional/ethnic groups in officer seniority cohorts in the Nigerian army, 1952-64.

\begin{tabular}{|l|c|c|c|c|c|}
\hline \multicolumn{1}{|c|}{ Seniority } & Igbo & Others & Yoruba & North & Total N= \\
\hline \multicolumn{1}{|c|}{ Cohort } & (South) & (South) & (South) & & \\
\hline Before '52 & 1 & 1 & 3 & 1 & 6 \\
\hline $1952-4$ & 3 & 3 & 1 & 3 & 10 \\
\hline $1955-6$ & 10 & 3 & 2 & 1 & 16 \\
\hline $1957-8$ & 11 & 2 & 2 & 2 & 17 \\
\hline $1959-60$ & 14 & 6 & 11 & 10 & 41 \\
\hline $1961-2$ & 24 & 8 & 12 & 32 & 76 \\
\hline $1963-4$ & 32 & 26 & 32 & 74 & 164 \\
\hline
\end{tabular}

Source: Robin Luckham (1971:187).

Table 5 highlights the ethnic origins of officer seniority across seven cohorts, and reaffirms in greater detail that, from 1961 onwards, the impact of the quota system was progressively in favour of northerners compared to the Igbo and Yoruba. 
Table 6: Regional/Ethnic origins of officers at different ranks in the Nigerian army in 1966.

\begin{tabular}{|l|c|c|c|c|c|}
\hline \multicolumn{7}{|c|}{ Rank } & $\begin{array}{c}\text { Igbo } \\
\text { (South) }\end{array}$ & $\begin{array}{c}\text { Others } \\
\text { (South)* }\end{array}$ & $\begin{array}{c}\text { Yoruba } \\
\text { (South) }\end{array}$ & North & $\begin{array}{c}\text { Total } \\
\text { (N) }\end{array}$ \\
\hline Colonels \& higher & 1 & 0 & 4 & 2 & 7 \\
\hline $\begin{array}{l}\text { Lieutenant } \\
\text { Colonels }\end{array}$ & 5 & 4 & 2 & 3 & 14 \\
\hline Majors & 21 & 2 & 7 & 2 & 32 \\
\hline Captains & 15 & 8 & 12 & 17 & 52 \\
\hline Lieutenants & 20 & 6 & 10 & 22 & 58 \\
\hline $\begin{array}{l}\text { Second } \\
\text { Lieutenants }\end{array}$ & 42 & 23 & 32 & 70 & 167 \\
\hline *This includes Igbo who inhabit parts of Igboland across the River Niger. \\
\hline
\end{tabular}

Source: Robin Luckham (1971:190).

Table 6 shows that in 1966, at the time when the corps was completely 'Nigerianized', "there was a concentration of Ibos (sic) in the middle levels of the army hierarchy" ${ }^{57}$, while most of the rank and file were from upper Niger ethnic groupings. Those middle layers of the officer corps consisted of lieutenant colonels and majors who were "split more or less evenly between Sandhurst graduates and ex-NCOs". ${ }^{58}$ Table 6 also shows that "there was a lower layer, at the level of captain and below, dominated (especially at the bottom) by the North" ${ }^{59}$ Furthermore, the North's control of political power at the centre was evident from the fact that "[m]ost of the key positions in the army below [General] Ironsi [who is Igbo] were held by Northerners" ${ }^{60}$ One could discern from the foregoing that recruitment patterns in the Nigerian army were largely responsible for the evolution of factionalism in the officer corps. Jenkins and Kposowa designated factionalism as a major cause of African coups. ${ }^{61}$

The statistics indicating the North's dominance of both the rank and file of the army from the outset and the officer corps after 1960 can be misleading and should be clarified to forestall anyone drawing the wrong inferences from them. For one, they hid crucial details about the heterogeneity of the upper Niger regions, which colonial state-building could not erase completely. One such detail is that the majority of neither the rank and file, nor the officers from the North, came from the 
core of the Caliphate society. They were, instead, from the fringes of Caliphate society, i.e. from discernible groups in the north that showed a historical aversion for Caliphate authority. ${ }^{62}$ Although most of those groups converted to Christianity, some of them mindfully remained politically correct, i.e. they still spoke the Hausa language and retained nominal adherence to Islam, as is evident in the Muslim names they bore. They are proof that the success of colonial social engineering in the upper Niger region was quite limited. ${ }^{63}$

Beginning with the first coup in 1966, the study on which this article is based, relied on vital demographic data regarding plotters of foiled and unsuccessful coups to argue reasonably that their actions amplify echoes of lop-sided recruitment patterns and the impacts of such patterns. However, the absence of vital demographic data on the plotters of successful coups makes it difficult to include them in this immediate assertion.

\section{The coup of January 15, 1966}

The coup of January 15, 1966 has been dubbed an 'Igbo coup' by Luckham, ${ }^{64}$ Martin Dent ${ }^{65}$, Miners, and Larry Diamond ${ }^{66}$ for the reason, evident in Table 7, that most of the plotters and executors were Igbo. But thorough sociological analysis of the coup and related events reveals otherwise. For one, the antecedents and utterances of the individual coup-makers do not indicate that they wanted to replace Hausa-Fulani hegemony with Igbo domination. Ruth First argues the same point that the coup was not meant to usher in Igbo political hegemony. ${ }^{67}$ Another point of argument that contradicts assertions made by the aforementioned scholars that the first coup was meant to promote Igbo political hegemony in Nigeria is that coup-day proclamations and narratives by survivors of the January 1966 coup indicate that their aim was to rescue the country from the autocracy of Hausa-Fulani rule. ${ }^{68}$

Table 7: The January 15, 1966 coup makers.

\begin{tabular}{|c|c|c|}
\hline & Rank/Name & Origin (Geographical/Ethnic) \\
\hline Majors & Nzeogwu & \multirow{6}{*}{ South (Igbo) } \\
\hline & Ifeajuna & \\
\hline & Okafor & \\
\hline & Anuforo & \\
\hline & Chukwuka & \\
\hline & Aghaya & \\
\hline
\end{tabular}


114

\begin{tabular}{|c|c|}
\hline Onwuatuegwu & \\
\hline Ademoyega & South (Yoruba) \\
\hline Captains Gbulie & \multirow{5}{*}{ South (Igbo) } \\
\hline Nwobosi & \\
\hline Oji & \\
\hline Udeaja & \\
\hline Ude & \\
\hline Lieutenants Oyewole & \multirow[t]{2}{*}{ South (Yoruba) } \\
\hline Adeleke & \\
\hline Ezeigbo & \multirow{7}{*}{ South (Igbo) } \\
\hline Second Lieutenants Azubuogor & \\
\hline Nwokocha & \\
\hline Ojukwu & \\
\hline Onyefuru & \\
\hline Igweze & \\
\hline Egbibor & \\
\hline Olafimihan & South (Yoruba) \\
\hline Ngwuluka & \multirow{3}{*}{ South (Igbo) } \\
\hline Nweke & \\
\hline Ikejiofor & \\
\hline
\end{tabular}

Source: N. J. Miners (1971:168).

Conclusions about the aims of the coup, drawn by scholars from the ethnicity of its plotters, are not supported by statistics regarding the composition of the officer corps at the time. One can interpret the figures gleaned from Table 7 to add credence to the logic that, given the composition of the Nigerian army at the time, the argument that the ethnic origins of individual officers in the group of plotters and executors of that first coup could not have been different. For instance, in a situation where most Northern officers owed their enlistment in the army to the same political leaders who were in power at the centre, it would be unrealistic to expect that the extensive disaffection felt in the country against the policies of the NPC-led federal government could have permeated officers from the North - if at all - as deeply as they permeated those from the South. It is evident from Table 7 that the representation of Yoruba officers in the group of plotters was anything but significant. Again, a logical explanation would be that, at that stage, the proportion of officers in the corps who were Yoruba was insignificant when compared with the proportions that were Igbo and from the North respectively. It would not be 


\section{5}

illogical, therefore, to argue that given the depth of disaffection in the land against the policies of the NPC-controlled central government at the time and the other relevant variables, including the absence of Yoruba officers in the corps, the Igbo, who comprised a significant proportion of the middle ranks in the corps, where most of the plotters belonged, were destined to dominate the roll of plotters. ${ }^{69}$

A closer look at Table 6 will suffice here to substantiate some of the immediate arguments made earlier in this article. Table 6 shows that 23 out of the 32 officers in the rank of major at the time were Igbo-which includes 2 Ika Igbo. Seven others were Yoruba, and the rest from the North. Table 7 shows that the representation of Igbo and Yoruba officers in the group of plotters tallied quite well with their respective proportions in the corps. There is additional evidence that, beyond their respective nationality of origin, the January 1966 coup plotters were brought together by another more important motive, i.e. the conviction that they had to use the army to rescue the country from the NPC-controlled federal government. ${ }^{70}$ In his personal account of the event, Major Ademoyega asserts that from the outset, all principal conspirators were driven by the ideal to rescue the country from a visionless political leadership. ${ }^{71}$ That may be why they "developed a number of linkages with one another as a result of their army careers". ${ }^{72}$ Seven of them - "Majors Nzeogwu, Chukwuka, Anuforo, Onwuatuegwu ... Captains Udeaja, [Ben] Gbulie, ${ }^{73}$ and Nwobosi overlapped each other at Sandhurst". ${ }^{74}$

The ruling NPC's colonial-style repressive tactics against perceived political opponents of Hausa-Fulani interests were bound to backfire. The deployment of the army by the NPC for internal colonial-style repression duties in the Middle Belt was most unpopular amongst the segment of the officer corps that plotted the coup. Such deployment may have reminded the coup plotters of the pacification activities of British-led colonial forces about whom they have learnt in history lessons and narratives amongst their respective nationalities. ${ }^{75}$ First's argument that the "coup grew out of the angry ... political purposes of young officers, who shared the disgust of their generation at the iniquity of the politicians, not least their use of the army to further their purposes"76 adds credence to the earlier argument.

Perhaps the NPC and its Hausa-Fulani leadership were unaware of the potentially negative implications of the composition of the corps for their penchant to deploy the army for internal repression duties. The disproportionate presence of indigenous men in the officer corps was a problem that posed a potential danger to the political dominance of the NPC, given the fact that their British allies had 
relinquished command and control of the army. If one were to remove the NPC from the configuration of politics in Nigeria at the time, and reinsert the British, leaving everything else untouched, chances are that the coup would still have taken place. $^{77}$

In a way, the coup is akin to the 1857 Sepoy Mutiny in India against British rule. The significant presence of indigenous peoples in the Indian colonial army altered what used to be a cordial relationship between British colonial administrators and the colonial army to such a degree that it provoked a violent backlash from the former. In the case of Nigeria, the presence of a significant number of indigenous men from southern groups altered the army's age-old relationship with those in power. One of the more obvious and immediate outcomes of this is the January 15, 1966 coup.

Table 8: Army and civilian targets and victims of the January 15, 1966 coup, alongside their statuses in the army and government at the time.

\begin{tabular}{|l|l|l|l|}
\hline \multicolumn{1}{|c|}{ Rank } & \multicolumn{1}{|c|}{ Status } & \multicolumn{1}{|c|}{$\begin{array}{c}\text { Ethnic/Regional } \\
\text { Origin }\end{array}$} & \multicolumn{1}{|c|}{ Fate } \\
\hline Maj. Gen. Ironsi & GOC & Igbo (South) & Escaped \\
\hline Brig. Ademulegun & CO $1^{\text {st }}$ Brig. & Yoruba (South) & Killed \\
\hline Brig. Maimalari & CO 2 $^{\text {nd }}$ Brig. & North & Killed \\
\hline Col. Mohammed & Chief of Staff & North & Killed \\
\hline Lt. Col. Pam & Adj. Gen. & North & Killed \\
\hline Lt. Col. Unegbe & Q/M Gen. & Igbo (South) & Killed \\
\hline Lt. Col. Largema & CO 4 ${ }^{\text {th }}$ Btn. & North & Killed \\
\hline Col. Shodeinde & $\begin{array}{l}\text { CO Nigerian Mil. } \\
\text { College } \\
\text { Dep. CO Nigerian } \\
\text { Defence Academy }\end{array}$ & Yoruba (South) & Killed \\
\hline
\end{tabular}




\begin{tabular}{|l|l|l|l|}
\hline \multicolumn{4}{|c|}{ Civilians } \\
\hline & \multicolumn{1}{|c|}{ Status } & \multicolumn{1}{|c|}{$\begin{array}{c}\text { Ethnic/Regional } \\
\text { Origin }\end{array}$} & Fate \\
\hline Balewa & $\begin{array}{l}\text { Prime Minister } \\
\text { (NPC) }\end{array}$ & North & Killed \\
\hline Ahamadu Bello & $\begin{array}{l}\text { Premier N. Reg. } \\
\text { NPC President }\end{array}$ & North & Killed \\
\hline Okotie-Eboh & Fin. Min. (NCNC) & Mid-West (South) & Killed \\
\hline
\end{tabular}

Source: Miners 1971 and Luckham 1971

The 1966 coup's list of targets and victims shown in Table 8 tends to vindicate the argument further that the coup was not meant to usher in Igbo domination. The targets and victims of the coup gave face to the NPC-controlled government and included General Aguiyi Ironsi (an Igbo), the General Officer commanding the army, who luckily escaped; Brigadiers Ademulegun (Yoruba) and Maimalari (Middle Belt Northerner) who were commanders of the First and Second Brigades respectively. Others included Colonel Mohammed (Northerner) the Chief of Staff, Lieutenant Colonel Pam (Middle Belt Northerner) the Adjutant General, Lieutenant Colonel Unegbe (Igbo) the Quartermaster General, Lt. Col. Largema (Middle Belt Northerner) officer commanding Fourth Battalion, and Colonel Shodeinde (Yoruba) Commander and Deputy Commander of the Nigerian Military College and the Nigerian Defence Academy respectively. Balewa (Northerner) and NPC Prime Minister, Bello (Northerner) and NPC leader and Northern Region Premier, and Okotie-Eboh (Itsekiri from the south) and the Federal Finance Minister, were the three civilians who were killed. Although most of these individuals were from the upper Niger region, the list included two Igbo and Yoruba officers as well. Major Nzeogwu himself asserted that the coup plotters targeted "people who were undesirable for the future progress of the country or who by their positions had to be sacrificed for peace and stability". ${ }^{78}$

\section{The 'counter-coup' of July 28-30, 1966}

The original intention of northern officers behind the so-called countercoup of July 1966 was a revolt to avenge the deaths of their benefactors in the January 15 coup and to excise the North from the rest of Nigeria. ${ }^{79}$ This is evident from the cultural/ethnic affiliations of their victims as shown in both Table 9 and Table 10 below. 
Table 9: Cultural/Ethnic affiliations of participants in the July 1967 revolt.

\begin{tabular}{|l|l|l|l|l|}
\hline & \multicolumn{3}{|c|}{ Cultural Origins (\% of Total)* } & \\
\hline Roles of Participants & $\begin{array}{l}\text { Dry } \\
\text { North }\end{array}$ & $\begin{array}{l}\text { Hausa- } \\
\text { Fulani } \\
\text { (Diaspora) }\end{array}$ & $\begin{array}{l}\text { Middle } \\
\text { Belt }\end{array}$ & N \\
\hline Operational Role & $37(10)$ & $44(12)$ & $19(5)$ & $\begin{array}{l}100 \\
(27)\end{array}$ \\
\hline Co-ordination, etc. & $33(3)$ & $56(5)$ & $11(1)$ & $\begin{array}{l}100 \\
(9)\end{array}$ \\
\hline All direct participants & $36(13)$ & $47(17)$ & $17(6)$ & $\begin{array}{l}100 \\
(36)\end{array}$ \\
\hline $\begin{array}{l}\text { Cultural origin of Northerners in } \\
\text { seniority cohorts to which } \\
\text { participants belonged }\end{array}$ & $36(33)$ & $33(36)$ & $31(34)$ & $\begin{array}{l}100 \\
(103)\end{array}$ \\
\hline
\end{tabular}

*Raw figures are in brackets.

Source: Robin Luckham (1971:78).

Table 9 indicates that $38(\mathbf{2 6 + 1 2 )}$ of the 72 northern officers (all direct participants) who played operational, coordination, and other roles, and who participated directly in the revolt were not even Hausa-Fulani. Only 34 (34) were Hausa-Fulani, while the other 38 were from regional groups that inhabited other parts of the upper Niger. Similarly, in terms of the cultural origin of participants in seniority cohorts, the number of officers (67) or 67\% from other northern groups was nearly double that of Hausa-Fulanis (36) or 33\%. These figures should give pause to anyone who would glean perfunctory meanings from the statistics on the composition of the army. There is credence, therefore, in earlier arguments about the complexity of society in the North.

Table 10: Ethnic and regional origin of the victims of the July 1967 revolt.

\begin{tabular}{|l|c|c|l|c|}
\hline Region & \multicolumn{2}{|c|}{ Deaths } & \multicolumn{1}{|c|}{ Ethnicity } & $\begin{array}{c}\text { Deaths } \\
\text { (Officers only) }\end{array}$ \\
\hline & Officers & Men & & 27 \\
\hline East (South) & 33 & 177 & Igbo (South) & 2 \\
\hline Mid-West (South) & 5 & 14 & $\begin{array}{l}\text { Non-Igbo } \\
\text { (South) }\end{array}$ & \\
\hline
\end{tabular}


119

\begin{tabular}{|l|c|c|l|c|}
\hline West (South) & 3 & 3 & $\begin{array}{l}\text { Non-Igbo } \\
\text { (South) }\end{array}$ & 6 \\
\hline North (South) & 0 & 0 & $\begin{array}{l}\text { Yoruba } \\
\text { (South) }\end{array}$ & 4 \\
\hline
\end{tabular}

Source: Robin Luckham (1971:76).

Table 10 shows that 27 out of the 39 officers killed were Igbo, four were Yoruba, while the other eight were from other southern nationalities. Of the enlisted men who were killed were Igbo. Going by the ranks of the principal actors in the event - the diseased were captains, lieutenants and second lieutenants - it is evident that they were all beneficiaries of the NPC's join-the-army campaign. The principal actor, Murtala Mohammed, was the nephew of Alhaji Inuwa Wada, the then Defence Minister in the NPC-controlled federal government. The timing and pattern of execution of the revolt indicate that it was the continuation of an on-going cleansing of Igbo residents of northern cities, in riots orchestrated by aggrieved Northern political leaders to avenge the death of their colleagues killed in the January 15 coup. ${ }^{80}$ The revolt became a coup only when non-Hausa-Fulani senior officers from the Middle Belt argued strongly against secession. ${ }^{81}$ The role of the officers in that regard indicated that unity between groups in the imagined community' of Northerners was underscored by suspicion on both sides. In later years, subsequent events confirmed this assertion even further. It was not lost on senior Middle Belt officers that a separate North would hardly function in their utmost interest. After those senior Middle Belt officers successfully argued against secession, one of them, Lt. Colonel Yakubu Gowon, an Angi, emerged as the new Supreme Commander and Head of State. After the mass purge of Igbo officers, which partly led to the secession attempt by the Igbo and to the Nigeria-Biafra war in 1967, the absence of officers from the Caliphate North in the senior cadres of the officer corps became an opportunity to which Middle Belt senior rankers availed themselves in both the army and politics of Nigeria in the period 1967-70, which marked the start and end of the war. Middle Belt officers quickly eased themselves into control of the army even as Mohammed and other Caliphate elements within and outside the army were obsessed with fighting a war against the Igbo. It was not until after Mohammed ousted Gowon in 1975 and the abortive counter in February 1976 by officers from non-Caliphate areas of the North in which Mohammad was killed, that the trial, execution and mass retirement of officers who were implicated in the coup shifted control of particularly the officer corps into the hands of officers from core Caliphate areas of the North. 


\section{The abortive coup of February 1976 and foiled plot of December 1986}

Even in the absence of up-to-date statistics regarding the composition of the Nigerian army in terms of ethnicity, ${ }^{82}$ demographic information on the composition of the officer corps, gleaned from the executions that followed the abortive coup against Mohammed's regime in 1976 and the foiled plot against Babangida in 1986, as shown in Tables 11 and 12 below, further underscores issues raised about the legacies of colonial and post-colonial recruitment patterns in the Nigerian military. For one, the absence of Igbo involvement in both events shows that the Igbo were yet to regain their presence in the corps. The predominance of officers from the non-Caliphate North in both executions further underscores the myth of a monolithic North. ${ }^{83}$

Table 11: Executed plotters of the 1976 coup.

\begin{tabular}{|l|l|l|l|l|}
\hline Rank & Name & State & Region & Religion \\
\hline Maj. Gen. & I. D. Bisalla & Plateau & Mid. Belt (N) & Christian \\
\hline Col. & A. D.S. Way & Kaduna & Southern Zaria (N) * & Christian \\
\hline & Isa Bukar & Borno & Core North & Muslim \\
\hline Lt. Col. & A. R. Aliyu & Bendel & Mid. West (S) & Muslim \\
\hline & Ayuba Tense & Plateau & Mid. Belt (N) & Muslim \\
\hline & K. Adamu & Plateau & Mid. Belt (N) & Muslim \\
\hline & A. B. Umaru & Kaduna & Southern Zaria (N) * & Muslim \\
\hline & B. S. Dimka & Plateau & Mid. Belt (N) & Muslim \\
\hline Major & M. M. Mshellia & Gongola & North & Muslim \\
\hline & I. B. Rabo & Kaduna & Southern Zaria (N) * & Muslim \\
\hline & Kephas K. & Plateau & Mid. Belt. (N) & Muslim \\
\hline & Gagara & & & \\
\hline & C. B. Dabang & Plateau & Mid. Belt. (N) & Muslim \\
\hline & Ola Ogunmekan & Ogun & South (Yoruba) & Muslim \\
\hline & S. Walias & Ogun & South (Yoruba) & Muslim \\
\hline & J. W. Kasai & Gongola & North* & Muslim \\
\hline & Kola Afolabi & Kwara & South (N. Yoruba) & Muslim \\
\hline & J. Idi Fadah & Plateau & Mid. Belt. (N) & Muslim \\
\hline Captain & G. Parwang & Plateau & Mid. Belt. (N) & Muslim \\
\hline & A. Dawurang & Plateau & Mid. Belt. () & Muslim \\
\hline & M. R. Gotip & Plateau & Mid. Belt. (N) & Muslim \\
\hline & A. A. Aliyu & Kaduna & Southern Zaria (N) * & Muslim \\
\hline & & & &
\end{tabular}


121

\begin{tabular}{|c|c|c|c|c|}
\hline Lt. & Mohammed & - & North & Muslim \\
\hline & K. Seleng & Plateau & Mid. Belt $(\mathrm{N})$ & Christian \\
\hline & William Seri & Plateau & Mid. Belt. (N) & Christian \\
\hline & Peter Cigari & Plateau & Mid. Belt. (N) & Christian \\
\hline & O. Zagni & Gongola & (North) & Christian \\
\hline & S. Wayah & Kaduna & Southern Zaria $(\mathrm{N})^{*}$ & Christian \\
\hline & Sabo Kwale & Gongola & North* & Christian \\
\hline W. O. & $\begin{array}{l}\text { Monday } \\
\text { Manchong }\end{array}$ & Plateau & Mid Belt (N) & Christian \\
\hline & $\begin{array}{l}\text { Sambo } \\
\text { Pankshin }\end{array}$ & Plateau & Mid Belt (N) & Christian \\
\hline & $\begin{array}{l}\text { Emmaneul } \\
\text { Dakup Seri }\end{array}$ & Plateau & Mid Belt (North) & Christian \\
\hline & Bawa & Plateau & Mid Belt $(\mathrm{N})$ & Christian \\
\hline Sgt. & $\begin{array}{l}\text { Richard } \\
\text { Dungdang }\end{array}$ & Plateau & Mid Belt (N) & Christian \\
\hline & Sale Pankshin & Plateau & Mid Belt (N) & Christian \\
\hline & Bala Javan & Plateau & Mid Belt $(\mathrm{N})$ & Christian \\
\hline & Ahmadu Rege & Kaduna & Southern Zaria $(\mathrm{N})$ * & Christian \\
\hline $\begin{array}{l}\text { Rtd. Pol. } \\
\text { Comm. }\end{array}$ & J. D. Gomwalk & Plateau & Mid. Belt. (N) & Christian \\
\hline Pol. Supt. & Shaiyan & Plateau & Mid. Belt. (N) & Christian \\
\hline Broadcaster & $\begin{array}{l}\text { Abdul Karim } \\
\text { Zakari }\end{array}$ & Kaduna & North & Christian \\
\hline
\end{tabular}

Source: S. A. Ochoche (1987:91).

Regarding the failed attempt of 1976 , Table 11 shows that $89.7 \%$ (35) of the 39 people who were executed for their involvement were Christians. This sectarian divide amongst officers from the North supports arguments about the failure of colonialism to build a homogenous conservative society out of the upper Niger. Moreover, the fact that $59 \%$ of those 35 people, which included Joseph Gomwalk, a former Police Commissioner and governor of Benue Plateau state ${ }^{84}$ and Gowon's brother in-law, were from the Middle Belt further underscores the 
immediate argument. The involvement of only one Yoruba could be interpreted to mean that other Yoruba officers chose to remain aloof of the coup events. ${ }^{85}$

Table 12: Executed plotters of the 1986 coup.

\begin{tabular}{|l|l|l|l|l|}
\hline Rank & Name & State & $\begin{array}{l}\text { Geographic } \\
\text { Region }\end{array}$ & Religion \\
\hline Major General & $\begin{array}{l}\text { Mamman } \\
\text { Vatsa }\end{array}$ & Niger & North & Muslim \\
\hline Lieutenant Colonel & Chris Oche & Benue* & Middle Belt & Christian \\
\hline & Mike Yorshe & & & Christian \\
\hline & $\begin{array}{l}\text { Musa } \\
\text { Bitiyong }\end{array}$ & Kaduna† & $\begin{array}{l}\text { Southern Zaria } \\
\text { (North) }\end{array}$ & Christian \\
\hline Wing Commander & Ben Ekele & Benue & Middle Belt & Christian \\
\hline & $\begin{array}{l}\text { Adamu } \\
\text { Sakaba }\end{array}$ & Sokoto† & North & Christian \\
\hline Navy Commander & $\begin{array}{l}\text { Achukwu } \\
\text { Ogwiji }\end{array}$ & Benue & Middle Belt & Christian \\
\hline Squadron Leader & Luther King & Lagos & South & Christian \\
\hline Major & D. Bamidele & Ondo & South (Yoruba) & Christian \\
\hline $\begin{array}{l}\text { Summary: } \\
\text { Total: 10: Christians (9); Muslims (1). } \\
\text { * Benue state was created from Plateau state. } \\
\text { †From non-Hausa-Fulani nationalities in the North. }\end{array}$ \\
\hline
\end{tabular}

Source: S. A. Ochoche (1987:90).

The pattern of the 1986 executions, as shown in Table 12, is similar. Nine out of the ten who were executed were Christians from the Middle Belt and two were Yoruba. Again no Igbo was involved. Only one Muslim was implicated and executed in that uncovered plot.

\section{The failed coup attempt of April 22, 1990}

There are echoes of the legacies of recruitment patterns in the 1990 failed coup by mostly officers and men from the so-called minority groups in the South, in the sense that the plotters vented their frustration over how they were being systematically prevented from advancement in their military careers. Forty-two participants were executed. However, the coup can best be understood in the 
context of the more rigorous discourse by this author elsewhere on the roots of political instability in Nigeria, and amongst the ethnic groups who inhabit it. ${ }^{86}$

\section{Conclusion}

Military coups are but one indicator of political instability or poor governmental performance in a country. Studying coups in case studies is most necessary particularly because of the extensive details furnished about them by doing so. The present case study of certain Nigerian coups was informed by that rationale.

Ochoche argued that Hausa-Fulani ruling classes, whose members lack effective dominance in the military, have perfected the ploy of utilising soldiers and officers from the non-core Caliphate areas of the North to undertake coups, only to push them aside and assume positions of power in the ensuing governments when the coups succeed. ${ }^{87}$ Ochoche further argues that in those situations where their coups attempts failed, they invoked another ploy of pushing those unfortunate individuals to the fore for execution as they themselves disappeared into the background. The absence of data on plotters of successful coups tends to rob Ochoche's argument of much of its validity.

Instead, there is more validity in the assertion that, given the inherent abnormalities evident in the Nigerian state, the legacy of all the lop-sided recruitment patterns produced and sustained an army that does not reflect the composition of the polity and society it was meant to serve. Morris Janowitz cautioned about the consequences for society and polity of a military that negates the composition of its parent society. ${ }^{88}$ In the case of the January 1966 coup, the army was used by idealistic officers from the South in their quest to rescue the country from what they considered the "backward NPC-controlled central government”. In the 1967 coup, it was the beneficiaries of the join-the-army campaign and preferential recruitment policies in the imagined community of Northerners who rose to avenge the death of their benefactors who had lost their lives in the 1966 coup.

Although the coup of 1967 eventually produced a military regime headed by an officer from the 'imagined community', it was not meant to uphold the existence of the North as part of Nigeria. Its architects were unmindful of the ephemeral nature of the 'imagined community'. The notion of 'One North, One People, One Voice, One Destiny ${ }^{89}$ hardly resonated deeply within all northern 
ethnic groupings. The obsession shown by Murtala Mohammad and other HausaFulani officers in fighting a war to quash Igbo secession pre-occupied their attention $^{90}$ even as officers from the non-core Caliphate nationalities in the North improved their circumstances in the military.

Murtala's 1975 coup to oust Yakubu Gowon was meant to retake the power he felt was unduly taken from them by Gowon and senior officers from the Middle Belt in 1967. Murtala's coup against Gowon was akin to a lid taken off a boiling pot. ${ }^{91}$ Its logical outcome was the counter-coup in 1976 by soldiers and officers from Gowon's part of the North to reinstate Gowon in power as one of their own. However, when this failed, their targets took the opportunity they found in the failure to step up their neutralisation of officers from the non-Caliphate north to further guarantee Hausa-Fulani control.

The large-scale executions and purge of 1976 hardly achieved sufficient success as these executions could not deter the plot of 1986, which led to the arrest, trial and execution of ten officers, nine of whom were, again, from the Middle Belt.

\section{Notes}

\footnotetext{
${ }^{1}$ Military recruitment including conscription "directly relate to many of the central issues in social science, including state-formation, state capacity, the legitimation of state, claims to citizen sacrifices, social stratification, nationalist or separatist socialisation, the spread of military skills, and the constitution of male identities". See Lars Mjøset (ed), "Introduction” in The Comparative Study of Conscription in the Armed Forces, Comparative Social Research, Volume 20, JAI, Elsevier Science (2002). However, military recruitment is largely neglected in the social sciences. Accounts that explain military coups in Africa neglect to examine such coups by taking colonial and post-colonial recruitment of soldiers in Africa into consideration. The study on which this article is based, begins the process of closing the gap created by that neglect.

${ }^{2}$ Nigeria's founding through colonial intervention in the period 1898-1914 without the consent of the distinct nationalities that were made to constitute it, qualifies Nigeria as a supra-national state.

${ }^{3}$ Before British intervention, Nigeria was not in existence. Nigeria is therefore an artificial polity that resulted from British colonial intervention.

${ }^{4}$ J. G. Frynas, "Political Instability and Business: Focus on Shell in Nigeria," Third World Quarterly 19, 3(1998):457-78.

${ }^{5}$ Murtala Muhammed's regime, which came to power after a successful coup d'état in 1975, was targeted the next year by the Dimka-led coup attempt in which Muhammed was killed. Ibrahim Babangida's regime that came to power in August 1985 in a successful coup d'état against the regime of Muhammadu Buhari foiled a coup plot in December the following year and survived an attempted coup in 1991.

${ }^{6}$ The various literatures are extensive. They include: Claude E. Welch, "Soldier and State in Africa,” Journal of Modern African Studies 5, 3(1967):305-22; Claude E. Welch, "Praetorianism in Commonwealth West Africa," Journal of Modern African Studies 10,
} 
2(1972):203-21; Larry Diamond, "Nigeria: The Uncivic Society and the Descent into Praetorianism,” in Larry Diamond, J. J. Lintz and S. M. Lipset, (eds), Politics in Developing Countries: Comparing Experiences With Democracy. (Boulder, CO: Lynne Rienner 1995); Christopher Clapham, "The Ethiopian Coup d'état of December 1960," Journal of Modern African Studies 6, 4(1968):495-507; Samuel Decalo, "Military Coups and Military Regimes in Africa," Journal of Modern African Studies 11, 1(1973):105-27; Samuel Decalo, Coups and Army Rule in Africa: Studies in Military Style (New Haven: CT: Yale University Press 1973); Ruth First, The Barrel of a Gun: Political Power in Africa and the Coup d'état (London: Penguin 1970); Samuel P. Huntington, Political Order in Changing societies New Haven, (CT: Yale University Press 1968); Tormod K. Lunde, "Modernization and Political Instability: Coups d'état in Africa 1955-1985," Acta Sociologica 34, 1(1991):13-32; Pat McGowan and Thomas H. Johnson, “African Military Coups d'état and Underdevelopment: A Quantitative Historical Analysis," Journal of Modern African Studies 22, 4(1984):633-666; Patrick J. McGowan, "African Military Coups d'état, 1956-2001: Frequency, Trends and Distribution,” Journal of Modern African Studies 41, 3(2003):339-370; J. Craig Jenkins and Augustine J. Kposowa, “Explaining Military Coups D'état: Black Africa, 1957-1984," American Sociological Review 55, 6(1990):861-875; J. Craig Jenkins and Augustine J. Kposowa, "The Political Origins of African Military Coups: Ethnic Competition, Military Centrality, and the Struggle Over the Postcolonial State,” International Studies Quarterly 36, 3(1992):271-291; J. Craig Jenkins and Augustine J. Kposowa, "The Structural Sources of Military Coups in Postcolonial Africa, 1957-1984,” American Journal of Sociology 99, 1( 1993):126-163; Patrick J. McGowan, "Coups and Conflict in West Africa, 1955-2004 Parts I and II," Armed Forces \& Society 32, 1(October 2005):5-23 and 2(January 2006):234-253.

${ }^{7}$ McGowan and Johnson, “African Military Coups,” (1984):634.

${ }^{8}$ Jenkins and Kposowa, Political Origins of African Military Coups, (1992); Kposowa and Jenkins, The Structural Sources of Military Coups in Postcolonial Africa, (1993).

${ }^{9}$ Britain's colonial policies in the Niger basin and elsewhere in Africa have hardly been studied for what they really were - state-building initiatives that established structures and substructures that served colonialism quite well in some cases, but malfunctioned extensively in the post-colonial era. Upon close scrutiny, it is evident that most of those policies were not autonomous actions that emanated from the British government. Instead, they were partly forced on Britain's 'men on the spot' who were driven by their ideological convictions and by local conditions. Anthony Kirk-Green identifies a category of these men in generic terms as being composed of the District Officers (DOs) or District Commissioners (DCs) and their superiors. Each one of them is "the field representative of the colonial government, the proverbial man-on-the-imperial-spot ... the symbol and the executive agent of Britain's imperial administrations”. See A. M. H. Kirk-Green, Britain's Imperial Administrators, 18581966, (London and New York: Macmillan Press and St. Martins Press 2000).

${ }^{10}$ The emphasis placed in the study on which this article is based, on the post-colonial era is vital and necessary and is meant to debunk any misunderstanding on the part of anyone who might use the absence of military coups during the colonial era to query the logic in the research question. The army under an all-British officer corps was quite different from the army after the departure of British officers and NCOs and their replacement by indigenous men. Jenkins and Kposowa (1990) and Kposowa and Jenkins (1993) characterise the latter as factionalism and imbued it with a considerable significance as a major cause of military coups in Africa while ignoring the relevant need to address its origin. By so doing Jenkins and Kposowa made factionalism in the military seem like a given and peculiar African pathology.

${ }^{11}$ Concrete data on nationality and religious identity can be gleaned on plotters of only failed and foiled coups but not on the plotters of successful coups. The decision to restrict the choice of units of analysis to unsuccessful and foiled coups is informed by this fact. 
${ }^{12}$ Robert Yin, Case Study Research: Design and Methodology, Second edition (Thousand Oaks, CA: Sage Publications 1994).

${ }^{13}$ Arend Lijphart, "Comparative Politics and the Comparative Method," American Political Science Review 65 (September 1971):682-693; and Yin, Case Study Research, 14-15.

${ }^{14}$ Beverly R. Dixon, Gary D. Bouma, G. B. J. Atkinson, A Handbook of Social Science Research, (New York: Oxford University Press 1987):108; Gary D. Bouma, The Research Process, (Melbourne: Oxford University Press 1996).

${ }^{15}$ Catherine Boone, "States and Ruling Classes in Postcolonial Africa: The Enduring Contradictions of Power," in State Power and Social Forces: Domination and Transformation in the Third World, (eds), Joel S. Migdal, Atul Kohl, and Vivienne Shue (Cambridge: Cambridge University Press 1994).

${ }^{16}$ Martyn Denscombe, Ground Rules for Good Research, (Buckingham and Philadelphia: Open University Press 2002):140.

${ }^{17}$ William F. Gutteridge, "Military and Police Forces in Colonial Africa," in Colonialism in Africa, 1870-1960 Volume 2. The History and Politics of Colonialism 1914-1960, (eds), L. H. Gann and Peter Duignan (Cambridge: At the University Press 1970):286-319.

${ }^{18}$ Claude E. Welch, Jr. "Continuity and Discontinuity in African Military Organisation,” The Journal of Modern African Studies 13, 2 (1975):229-248.

${ }^{19}$ W. F. Gutteridge, The Military in African Politics (London: Methuen 1969).

${ }^{20}$ Robin Luckham, The Nigerian Military: A Sociological Analysis of Authority and Revolt, 1960-67 (Cambridge: At the University Press 1971):231.

${ }^{21}$ N. J. Miners, The Nigerian Army, 1956-1966 (London: Methuen 1971).

${ }^{22}$ This used to be true for the West African Frontier Force before it was decentralised.

${ }^{23}$ The British first intervened in the internal affairs of the Yoruba island kingdom of Eko, which the Portuguese called Lagos first in 1851 when they established a consulate there and annexed it finally in 1861. See Robert S. Smith, "The Lagos Consulate, 1851-1861: An Outline,” Journal of African History 15, 3 (1974):393-416, and The Lagos Consulate, 18511861 (Berkeley and Los Angeles: University of California Press).

${ }^{24}$ A. M. H. Kirk-Green, "A Preliminary Note on New Sources for Nigerian Military History," Journal of the Historical Society of Nigeria 3 (1964):129-47; Miners, The Nigerian Army. Also see S. O. Biobaku, The Egba and their Neighbours, 1842-72 (Oxford: Clarendon Press 1957), W. D. McIntyre, "Commander Glover and the Colony of Lagos, 1861-73," Journal of African History 4, 1(1963):57-79.

${ }^{25}$ Frederick Lugard was Britain's more accomplished empire builder. He entered the "Royal Military College, Sandhurst, 1878; commissioned in the $9^{\text {th }}$ Foot (Norfolk Regiment), 1878; on active duty in India until 1887; served on Gordon Relief Mission, 1885; received DSO for work as transport officer in the Burmese War, 1885-6; raised and commanded West African Frontier Force, 1897-9; High Commissioner, Northern Nigeria, 1900; Governor, Hong Kong, 1907; Governor, Northern and Southern Nigeria, 1912-13; governor-general, Nigeria, 191419 ...”, see John M. Carland, The Colonial Office and Nigeria, 1898-1914 (Stanford, California: Hoover Institution Press Stanford University 1985):xvi.

${ }^{26}$ Miners, The Nigerian Army, 1956-1966, (1971).

${ }^{27}$ This is evident in the oath of office that he wrote and made them swear to which runs as follows: "I, swear, in the name of Allah and Muhammad his prophet, to serve well and truly His Majesty King Edward VII and his representative, the "High Commissioner" of Northern Nigeria, to obey the laws of the Protectorate and the lawful commands of the "High Commissioner" and of the Resident, provided they are not contrary to my religion. And if they are contrary, I will at once inform the Resident for the information of the "High Commissioner". I will cherish in my heart no treachery or disloyalty, and I will rule my people with justice, and without partiality. And as I carry out this oath, so may Allah judge me”, see 
A. E. Afigbo, "The Consolidation of British Imperial Administration in Nigeria, 1900-1918," Civilization 21, 4(1971):443-58.

${ }^{28}$ Gutteridge, Military and Police Forces in Colonial Africa, (1970).

${ }^{29}$ In a recent interview, veteran Nigerian nationalist Chief Anthony Enahoro disclosed that the resultant feeling of contempt between Lugard and Western-educated southerners was mutual though. The story goes that Lugard, after assuming office in Lagos as Governor-General in 1914, had summoned African leaders in Lagos to his house for a meeting as he used to summon the Hausa-Fulani rulers during his tenure in the north as High Commissioner. But no one honoured his summon. Instead, they responded by informing him that tradition, which was adhered to strictly by his predecessors, was to request them to receive them in a meeting whenever the need arose.

${ }^{30}$ In other to avoid ambiguity, it is pertinent that I put these assertions in their proper historical context. As High Commissioner Lugard never hid his determination to protect the imperial outpost he was building in the upper Niger from what he considered the polluting influence of "the agents of social and economic change - the Christian missionaries, the European traders, and the coastal traders", Anthony I. Nwabughogu, "The Role of Propaganda in the Development of Indirect Rule in Nigeria 1890-1929,” The International Journal of African Historical Studies 14, 1(1981):65-92. Lugard cited the propensity of Western-educated African residents of Lagos to avail themselves of the courts and the rule of law to litigate against British authority as his reason for opposing their unfettered presence in the upper Niger. See "Lugard to Colonial Office”, 1901 in Colonial Office Confidential 879/88(789):1920. Lugard derided their propensity for trade and commerce as unsightly love for the dollar, see Margery Perham, Lugard: the Years of Authority, 1895-1945 (London: Collins 1960), employed a conscious urban policy to segregate people from the lower Niger and the upper Niger respectively from each other all over the urban centres in the upper Niger. The result was the various sabon gari or strangers' quarters located outside city limits in upper Niger cities, exclusively for individuals from the lower Niger. See Frederick Lugard, Political Memoranda: Revision and Instructions to Political Officers on Subjects Chiefly Political and Administrative, 1913-1918 (London: Frank Cass 1918-1970).

${ }^{31}$ Lagos and its residents exerted a tremendous measure of influence on anti-colonial attitude and activities in the lower Niger and all over the urban areas in Nigeria for reasons that derive from the country's history as a Crown Colony in the period 1851-1914. The freed slaves who returned and settled in Lagos and their supporters in England saw themselves as full-fledged British subjects with rights and privileges. They possessed Western education and were integrated into the affairs of the Crown Colony from the outset. With time, indigenous Lagosians and others took a cue from the returnees and embraced Western education and culture, which in turn earned them some integration. All integration was shattered when formal colonial rule was imposed in Lagos and the rest of the areas that became Nigeria in 1914. The result of that imposition was that the returnees and other Western-educated Lagosians became increasingly disaffected towards colonial authority. This was how Lagos became the cradle of anti-colonial agitation, which then spread to other urban centres, including those in the upper Niger, particularly amongst lower Niger peoples who resided in the various sabon gari. See E. C. Ejiogu, The Roots of Political Instability Amongst Indigenous Nationalities and in the 'Nigerian' Supra-National State, 1884-1990, A Longitudinal and Comparative Historical Study. Unpublished Doctor of Philosophy Dissertation, Department of Sociology, University of Maryland, College Park (2004).

${ }^{32}$ A. Haywood and F. A. Clark, The History of the Royal West African Frontier Force (Aldershot: Gale and Polden 1969).

${ }^{33}$ Miners, The Nigerian Army, 1956-1966, (1971), and Gutteridge, Military and Police Forces in Colonial Africa, (1971). 
${ }^{34}$ Events later proved the cliché about the potential dangers that came to pass when coups and other tragic events of political instability started to pile up.

${ }^{35}$ Gutteridge, Military and Police Forces in Colonial Africa, (1971):304.

${ }^{36}$ Colonialism's ambition to create a homogenous society of loyal subjects in the upper Niger was hardly realised. That failure resonated in the refusal of non-Caliphate parts of the upper Niger to accept their subjection as part of the 'homogenous North'. This echo has been heard in some of the coups, as I will detail in the discourse later.

${ }^{37}$ Islam's antecedents in parts of Yorubaland were influenced by Yoruba culture. Islam was introduced in northern Yorubaland by Fulani traders in about 1840, long after the Fulani jihad had influenced the course of politics in Hausaland, but at no stage did the Fulani jihad translate to direct Fulani interference in the practice of the faith in the heart of Yorubaland. The only exception was in Ilorin in northern Yorubaland, which was captured and occupied by Fulani jihadists in 1874. The reason for that exception partly derived from the exodus of the majority of the Yoruba from the town after the Fulani jihadists captured it. The influence of traditional Yoruba norms was so pervasive on Islam that in some Yoruba Muslim communities, succession to the office of Imam was through the bloodline of the individual through whom the faith was introduced. Seniority became one of the qualifications; it was customary for a new Imam to be introduced to the political head of a town before he could assume his responsibilities. Whenever the Muslim community in some Yoruba towns felt impressed by the Koranic knowledge of an itinerant cleric from Sokoto, they prevailed on him "to stay and lead the community as Imam" (T. G. O. Gbadamosi "The Imamate Question among Yoruba Muslims". Journal of Historical Society of Nigeria 6, 2(1972):232. Such individuals stayed and functioned strictly in their religious capacity within the community. Yoruba Muslims are known to see themselves first as Yoruba, and then as Muslims. Also see detailed discussion of this in E. C. Ejiogu, The Roots of Political Instability Amongst Indigenous Nationalities and in the 'Nigerian' Supra-National State, 1884-1990, (2004).

${ }^{38}$ Loyalty to Britain was not in short supply thereafter among the Hausa-Fulani ruling classes. In his 1913 Annual Reports, E. J. Arnett, the "Resident" in charge of Sokoto "Province disclosed that, "The Sarkin Musulimi aided by the Waziri and Majidadi has continued to give every satisfaction in carrying out loyally the policy of the government'. See John Paden, Ahamadu Bello Sardauna of Sokoto: Values and Leadership in Nigeria (London, Sydney, Auckland, and Toronto: Hodder and Stoughton 1986):85.

${ }^{39}$ G. I. Jones, "Ecology and Social Structure Among the North-Eastern Ibo," Africa 31 (1961):117-134.

${ }^{40}$ The story is similar in Yorubaland. See Akinjide Osuntokun, "Disaffection and Revolts in Nigeria During the First World War, 1914-1918," Canadian Journal of African Studies 4, 2(1971):171-192.

${ }^{41}$ A. E. Afigbo, "Revolution and Reaction in Eastern Nigeria: 1900-1929," Journal of the Historical Society of Nigeria 3, 3(1966):539-37.

${ }^{42}$ Miners, The Nigerian Army, 1956-1966, (1971), Afigbo, 1966, Haywood and Clark, ibid. In the official lexicon of the Nigerian army, this operation is called the yakin mata, 'women's war' in Hausa language, which was also the designated official language of the army.

${ }^{43}$ Gutteridge, Military and Police Forces in Colonial Africa (1970) \& Gutteridge, The Military in African Politics (1975).

${ }^{44}$ My preference for the concept of nationality is based on Coleman's conceptualization of a nationality: "A people distinguished from other peoples by one or more common cultural traits (a common language, a shared historical tradition, a common mythology as to origin, or similar customs). A nationality is the largest traditional African group above a tribe, which can be distinguished from other groups by one or more objective criteria (normally language). Present or recent political unity is not necessarily characteristic of a nationality, although such unity no 
doubt prevailed in the original core group (tribe) from which many of the 'Nigerian' nationalities have developed historically. The concept of "nationality", ... is considered essential for any working classificatory scheme for 'Nigerian' social and political groupings.... [w] hereas several nationalities are both potential and incipient nations (for example the Hausa, the Yoruba, the Igbo), others are too small or awkwardly situated to become nations. In sum, the concept of nationality is simply a convenient intermediate category introduced to refer to a people larger in population than a tribe, which is not yet and may never be a nation, but offers the strongest cultural basis for nationhood at the highest level and on the largest scale of all traditional African groupings" - see James S. Coleman Nigeria: Background to Nationalism. (Berkeley: University of California Press 1958):423.

${ }^{45}$ Miners, The Nigerian Army, 1965-1966, (1971).

${ }^{46}$ Wale Ademoyega, who was one of the principal architects of the January 15, 1966 coup, alleged in his narrative on the coup that "It was they [the British] who suggested to the Sardauna/Balewa government that it would take six full years from 1959 to Nigerianize the army completely, and that it was in the interest of NPC [the Hausa-Fulani political party] oligarchy to agree to the plan. That oligarchy agreed to the plan and did nothing either to hasten the process or alter the plan" - Adewale Ademoyega, Why We Struck: The Story of the First Nigerian Coup (Ibadan: Evans Brothers Nigeria Publishers Limited 1981):24. Adewale died recently in March 2007.

${ }^{47}$ Unlike in the upper Niger, inhabitants of the lower Niger took quickly to Christianity and Western education, both of which were propagated simultaneously by Christian missionaries.

${ }^{48}$ Robin Luckham, The Nigerian Military: A Sociological Analysis of Authority and Revolt, 1960-67 (Cambridge: At the University Press 1971):244.

${ }^{49}$ Luckham, The Nigerian Military, (1971):244.

${ }^{50}$ Ademoyega, Why We Struck: The Story of the First Nigerian Coup (1981):23, paints the vivid picture of how in contrast to their Southern counterparts, Northern cadet candidates showed blatant over-confidence during their pre-qualifying test: "When we were brought together with those cadets in the process of being tested, we observed that those of them who were Northerners were more carefree and more confident of sailing through. Those from the South were so afflicted by the fear of failing that they wore t he look of anxiety and bewilderment. In the course of our discussion, the cadets [from the South] made it clear to us that less than half of their own group would be selected and that Northerners were already billed to be $50 \%$ of the total number to be selected".

${ }^{51}$ Ademoyega, Why We Struck: The Story of the First Nigerian Coup (1981).

${ }^{52}$ Gutteridge Military and Police Forces in Colonial Africa (1970), Miners The Nigerian Army, 1965-1966, (1971).

${ }^{53}$ Miners, The Nigerian Army, 1965-1966, (1971):27.

${ }^{54}$ Results from that census awarded $54.5 \%$ of the population to the Northern Region, and $23 \%$ and $20 \%$ to the Eastern and Western Regions respectively.

${ }^{55}$ Luckham, The Nigerian Military (1971):208. In a recent personal letter in my possession by Sir Peter Smithers, a member of the British Parliament and Parliamentary Secretary to the British Secretary of State Alan Lennox-Boyd in 1952 indicated that the 1959 election that ushered in Nigeria's political independence the next year was rigged by British colonial administrators on behalf of the Hausa-Fulani ruling classes.

${ }^{56}$ Luckham, The Nigerian Military (1971):208.

${ }^{57}$ Luckham, The Nigerian Military (1971):186.

${ }^{58}$ Luckham, The Nigerian Military (1971):186.

${ }^{59}$ Luckham, The Nigerian Military (1971):189.

${ }^{60}$ Miners, The Nigerian Army, 1965-1966 (1971):157. 
${ }^{61}$ Jenkins and Kposowa, Political Origins of African Military Coups, (1992) and Kposowa and Jenkins, The Structural Sources of Military Coups in Postcolonial Africa, (1993).

${ }^{62}$ Some of those groups - the Tiv or Munshi, Numan, Tangele, Dakakor, and others - that inhabit hilly Jos Plateau areas later percolated and started to agitate for political separation from the Caliphate North as the Middle Belt Region.

${ }^{63}$ The Caliphate Empire, which Usman dan Fodio imposed in the wake of their jihad, which began in 1803 in Hausaland and parts of the greater upper Niger, and even southwards in northern Yorubaland, was a supra-national state. Typically, its political performance was wholesome only in Hausaland, particularly because the victorious Fulani assimilated into the Hausa culture, adopted the Hausa language as lingua franca, and co-opted the Hausa ruling classes that they ousted from power into the new Caliphate-style state they established and even modelled on the autocratic authority patterns of the ancien regime in Hausaland. The fission of the two peoples, i.e. Hausa and Fulani and their cultures gave rise to the new HausaFulani nationality in Hausaland. The Kanuri, Gwari, and other groups in the upper Niger who were also conquered in the jihad remained openly restive under Hausa-Fulani rule up to the advent of British rule in 1904. In fact, some of them misread Lugard's victory over the Caliphate rulers as a signal to rise up in rebellion to shake off Caliphate rule. Their attempts were crushed in combined British Hausa-Fulani onslaughts. See R. A. Adeleye, "Mahdist Triumph and British Revenge in Northern Nigeria: Satiru 1906”, Journal of the Historical Society of Nigeria 6, 2(1972):193-214. On the one hand, colonialism helped to reaffirm Caliphate rule over them. On the other, it extended colonial authority over other groups in the upper Niger that successfully resisted conquest by the Fulani in the jihad.

${ }^{64}$ Luckham, The Nigerian Military (1971).

${ }^{65}$ Martin J. Dent, “The Military and Politics: A Study of the Relations Between the Army and the Political Process in Nigeria, in Nigeria: Modernization and Politics of Communalism, (eds), Robert Melson and Howard Wolpe (Lansing: Michigan State University 1971).

${ }^{66}$ Larry Diamond, Class, Ethnicity and Democracy in Nigeria (Syracuse, NY: Syracuse University Press 1988).

${ }^{67}$ She argues that the "coup was not an Ibo (sic) coup with motives of tribal (sic) domination. It was a coup conspired by widespread political grievances". Ruth First, Power in Africa (New York: Pantheon Books, Random House 1971).

${ }^{68}$ See Wale Ademoyega, Why We Struck: The Story of the First Nigerian Coup (1981).

${ }^{69}$ Accounts of the coup by surviving plotters substantiate the fact that the plotters made the conscious decision to exclude their senior counterparts, most of whom they believed had been tainted by their fraternisation with politicians.

${ }^{70}$ Ademoyega was specific about this when he asserted that as early as the time when they went for enlistment at the Selection Board that sat in the northern city of Kaduna, those of who later participated in the January 1966 coup were well received by the then Lieutenant Emmanuel Ifeajuna, who "introduced them to other officers" and proceeded to discuss "the political turn of events in Nigeria and unanimously came to the conclusion that the military was likely to be the only solution", see Ademoyega, Why We Struck: The Story of the First Nigerian Coup (1981):24-25.

${ }^{71}$ Ademoyega, Why We Struck: The Story of the First Nigerian Coup (1981):24-25.

${ }^{72}$ Luckham, The Nigerian Military (1971):30.

${ }^{73}$ Gbulie's account of the coup is entitled Nigeria's Five Majors.

${ }^{74}$ Luckham, The Nigerian Military (1971):30.

${ }^{75}$ In an interview that he gave to the Nigerian Tribune of July 2, 1967, Major Chukwuma Kaduna Nzeogwu, one of the planners of the coup, referred specifically to their concern over such deployments when he said: 'The public is still largely unaware of the fact that a gigantic military operation over the Western Region was to swoop down on that territory on January 17. 
The incident that associated with January 15 today was to take place sometime later - that is the following month. Therefore, the significance of the state of emergency due to be proclaimed on January 15 must necessarily take place before the dawn of January 17' in Luckham The Nigerian Military (1971):41.

${ }^{76}$ First, Power in Africa (1971):300.

${ }^{77}$ The relevance of this observation applies to those who would argue that the marked absence of coups during colonial rule could be proof that colonial recruitment patterns could not necessarily have inspired coups. Such arguments overlook the difference that an all-British officer corps made in the army during colonial rule. The dynamics could have been similar to what occurred in 1966, had the corps been indigenised but the British were still in charge of the state and running it the same way as the NPC.

${ }^{78}$ Luckham, The Nigerian Military (1971):31.

${ }^{79}$ Unlike other coups, the July 1967 revolt lacked the character of coups: No spokesperson was designated or had taken to the airwaves to announce the coup.

${ }^{80}$ Luckham, The Nigerian Military (1971).

${ }^{81}$ Luckham, The Nigerian Military (1971).

${ }^{82}$ Since 1970, statistics on the composition of the army are kept under wraps by every Nigerian government in power.

${ }^{83}$ These are non-Fulani peoples that inhabit parts of the upper Niger. They include some groups who are of Hausa stock, the Kanuri, Gwogwola (Gongola), and the so-called pagan tribes of the stony and hilly parts of the Jos plateau. In addition to their respective languages, they all speak and understand the Hausa language. For reasons that derive from pre-colonial conquests and even British colonial administrative policies, some of them have nominal association with Islam. Their resistance against the rule of the Habe kings and the Fulani was extensive and legendary. In fact, their ready embrace of Christianity was a function of that fact. But contrary to their expectation, in spite of their conversion, colonialism still delivered them to Hausa-Fulani political control under the auspices of indirect rule.

${ }^{84}$ As governor in Gowon's regime, he incurred the wrath of Hausa-Fulani ruling classes over some of his policies that were deemed inimical to the continued existence of the "one North fraternity". His creation of "separate institutions in direct rivalry to those of the Interim Common Services Agency - [put in place to perpetuate] common forum for continued Northern fraternisation sequel to the break-up of the [monolithic] north into six states in 1967", see Bala. J. Takaya, "Socio-Political Forces in the Evolution and Consolidation of the Kaduna Mafia” in The Kaduna Mafia: A Study of the Rise, Development and Consolidation of a Nigerian Power Elite, (eds), Bala J. Takaya and Sonni Gwanle Tyoden (Jos: Jos University Press 1987):61.

${ }^{85}$ Officers and civilians of Yoruba origin functioned mostly as technocrats in the government during and after the prosecution of the war against Biafra. In his role as the Federal Commissioner for Finance and Vice Chairman of the Federal Executive Council, Chief Awolowo was credited with running the war economy for Gowon. Yoruba officers held all the successful commands that pushed their way into Biafra. But no Yoruba was involved in the clandestine 'War Council' based in the northern city of Kaduna, which existed independent of the official set-up in Lagos. The council was largely responsible for "the successful prosecution of the war”. See S. G. Tyoden, in Kaduna Mafia, (1987):68-83.

${ }^{86}$ See E.C. Ejiogu, Unpublished Doctoral Dissertation, (2004), in which I furnished a rigorous historical inquiry into the roots of the continuing poor political performance in the Nigerian state from the perspectives of Harry Eckstein's congruence theory and the derivative framework from it that was called the E-G scheme. The study argued that there is a high degree of social, economic, and political heterogeneity amongst the diverse nationalities including the Igbo, Yoruba, and Hausa-Fulani - that were compelled to constitute it, evident in 
their governmental and non-governmental authority patterns, hence, the assertion that Nigeria is a supra-national state. I argued further that the British, who were impressed by the inherent autocratic traits of the Hausa-Fulani, but not the obviously democratic traits of the indigenous Igbo, and Yoruba authority patterns, formulated and implemented state-building policies that preferentially favoured the Hausa-Fulani but not the Igbo, the Yoruba, and others. Thus, while there emerged tremendous resemblances between the authority patterns of the Nigerian supranational state and those of the Hausa-Fulani, there emerged deep-seated disparity between the authority patterns of both the supra-national state and the Hausa-Fulani and the indigenous Igbo, and Yoruba authority patterns. The resultant state of affairs created and promoted commensurate bases of legitimacy for the authority of the supra-national state only in core Hausa-Fulani society but not in Igbo and Yoruba societies. It was such that during colonial rule high political performance in the Nigerian supra-national state was region-specific. Hence the conclusion that in spite of the resemblances shared by the authority patterns of the supranational state and indigenous Hausa-Fulani authority patterns, their common incongruence and inconsonance with the indigenous authority patterns of the Igbo, Yoruba, and others constitute sufficient ground for the continuing poor political performance in the Nigerian supra-national state. Military coups have been one of the manifest indicators of that state of affairs.

${ }^{87}$ S.A. Ochoche, Political Manipulation and Scheming by the Kaduna Mafia in TheKaduna Mafia (1987):68-83.

ibid.

${ }^{88}$ M. Janowitz, The Professional Soldier: A Social and Political Portrait (Glencoe, Ill.: The Free Press 1960).

${ }^{89}$ S. G. Tyoden, in The Kaduna Mafia (1987).

${ }^{90}$ Tyoden, in The Kaduna Mafia (1987):74.

${ }^{91}$ Forthcoming memoirs by veteran politician, Chief Anthony Enahoro who was a prominent actor in the Gowon regime will detail much of the evidence that underscores this point. 